Roubos, K., M. Moustakas and F. A. Aravanopoulos (2010): Molecular identification of Greek olive (Olea europaea) cultivars based on microsatellite loci. Genetics and Molecular Research 9(3): 1865-1876.

Shrestha, M. K., H. Volkaert and D. V. D. Straeten (2005): Assessment of genetic diversity in Tectona grandis using amplified fragment length Polymorphism markers. Canadian Journal of Forest Research 35(4): 1017.

Slatkin, M. (1987): Gene flow and the geographic structure of natural populations, Science 236: 787-792.

Varghese, M., A. Nicodemus, P. K. Ramteke, G. Anbazhagi, S. S. R. Bennet and K. SubramanIAN (2000): Variation in growth and wood traits among nine populations of teak in Peninsular India. Silvae Genetica 49: 201-205.

VArshney, R. K., A. Graner and M. E. Sorrells (2005): Genic microsatellite markers in plants: features and applications. Trends Biotechnol. 23: 48-55.

Verhaegen, D., D. Ofori, I. Fofana, M. Poitel and A. VAILlANT (2005): Development and characterization of microsatellite markers in Tectona grandis (Linn. f). Molecular Ecology Notes 5(4): 945-947.

Verhaegen, D., I. J. Fofana, Z. A. Logossa and D. OFORI (2010): What is the genetic origin of teak (Tectona grandis L.) introduced in Africa and Indonesia? Tree genetics and genomes 6: 717-733.

White, K. J. (1991): Teak: Some aspects of research and development. RAPA publication, Bangkok.

\title{
Investigation of gas exchange and biometric parameters in isogenic lines of poplar differing in ploidy
}

\author{
By L. Atanet Alía ${ }^{1)}$, D. LÜttschwageR ${ }^{2)}$ and D. EwalD ${ }^{3), * *}$
}

(Received 6 ${ }^{\text {th }}$ August 2015)

\begin{abstract}
Three poplar clones of section Populus (Brauna 11 [Populus tremula], L447 [Populus canescens] and Esch 5 [Populus tremula x Popu-

1) LuCÍA ATANET ALÍA, Leibniz-Center for Agricultural Landscape Research (ZALF). Institute of Landscape Biogeochemistry, Eberswalder Straße 84, D-15374 Müncheberg, Germany. Phone: +34659295403, Fax: +493343282343. E-Mail: luciaatanet@hotmail.com

2) DietMar LÜtTSChwager, Leibniz-Center for Agricultural Landscape Research (ZALF). Institute of Landscape Biogeochemistry, Eberswalder Straße 84, D-15374 Müncheberg, Germany. Phone: +493343282108, Fax: +493343282343. E-Mail: dluettschwager@zalf.de

3) Thünen-Institute of Forest Genetics, Eberswalder Chaussee 3a, D-15377 Waldsieversdorf, Germany.

*) Communicating author: Dietrich Ewald. Phone: +4933433157170, Fax: +4933433157199. E-Mail: dietrich.ewald@ti.bund.de
\end{abstract}

lus tremuloides]) were used to analyse the effects of ploidy levels on primary productivity and water use efficiency. The clones were established in tissue culture $(2 \mathrm{~N})$ and lines with different ploidy levels $(2 \mathrm{~N} / 4 \mathrm{~N}$ and $4 \mathrm{~N})$ were generated via colchicine treatment. Light response curves were modelled based on gas exchange measurements carried out three times during the growing season on the $1^{\text {st }}$ fully developed leaf under controlled conditions. The plants were harvested in September to analyse biometric parameters. The photosynthetic capacity was greatest in May, decreased throughout the season and increased slightly again in September. The decrease in Brauna 11 and Esch 5 varied from 20-50\% compared with values in May and it was not as pronounced in L 447. Photosynthesis and intrinsic water use efficiency differed between clones, but not among the single isogenic lines within each 
clone. The seasons in which the experiments were conducted influenced the rankings of the 9 variants in physiological measurements, but these rankings were not uniform during the growing period. Differences in biometric parameters were detected between the clones and variants, e.g.; leaf masses were greater in all of the polyploid variants and lowest in the diploid variants. All of the L 447 lines showed the highest wood densities, which were higher in the mixoploid and lower in the tetraploid variants within each clone. A compact wood structure could prevent damage to the water-conducting system under drought stress.

Key words: poplar, diploid, mixoploid, tetraploid, net photosynthesis, water use efficiency, specific leaf area, photosynthetic capacity, light response curve, wood density.

\section{Introduction}

Since the first triploid tree showing high growth performance and resistance traits were discovered, (MÜNTZIG, 1936; NILSSON-EhE, 1936), the breeding of polyploid individuals has become goal of breeders. Nevertheless, the ultimate success of breeding and of using polyploids in forestry was restricted by the long life cycle of most trees. This was not the case in horticulture, where triploids yield superior fruit quality and size (EWALD et al., 2009), and often possess improved characteristics compared with their diploid counterparts with respect to morphological changes (WANG et al., 2014).

Because of their rapid juvenile growth, amenability to intensive culture, economic interest related to bioenergy, and high utility for a wide variety of wood and fibre products, trees of the genus Populus, and particularly their specific hybrids, have been studied for several decades (Monclus et al., 2006; Ceulemans, 1990; DickMANn et al., 1983; GoRDON et al., 1976; DiCKMANn et al., 1975). Poplars exhibit some of the highest $\mathrm{CO}_{2}$ exchange rates and leaf photosynthetic capacities among woody plants, and this production and resource utilisation is under strong genetic control (NELSON et al., 1984). In addition, these trees are noted for their higher water use compared with other forest species. High net photosynthesis (A) and intrinsic water use efficiency ( $\mathrm{WUE}_{\text {intr }}$ ) and tolerance to water deficits are critical links between poplar wood production and water management in dry regions (MoncLus et al.,
2006). Thus, global warming and the expected water limitation will likely significantly impact Poplar cultivation in areas with poor soil and limited annual precipitation. Especially poplars of the section Populus (former Leuce), that have been chosen for these experiments, fulfill better the demand for drought tolerance, compared with hybrid poplars (Aigeiros x Tacamahaca). Knowledge of the variation in the physiological and morphological parameters of the available plant material is required, and breeding programmes should consequently focus on new rapidly growing clones and combinations (ZSUFA et al., 1996). The findings of Monclus et al. (2009) suggest that it should be possible to select genotypes combining higher productivity, water use efficiency and drought tolerance. The link between tree genetics and physiology in poplars provides attractive challenges for collaboration between these two disciplines (STETTLER et al., 1993). Natural polyploids exhibit genetic effects of polyploidy in some cases and due to the altered genetic regulation of metabolism. In light of the widespread success of some polyploid plants, it would appear that polyploidy can confer adaptive advantages, such as higher photosynthetic rates and, consequently, higher biomass accumulation (XU et al., 2014), as well as enhanced resistance to environmental stresses, such as drought, salt and cold. Polyploidy can also cause variation in morphology (LEAL-BERTIOLI et al., 2012). In species with a range of ploidy levels, one particular ploidy level might be the most productive, as was demonstrated by QI et al. (2010), who found that leaf photosynthetic characteristics were enhanced in polyploid Populus ussuriensis. This result is supported by the findings of WARNER et al. (1993), who observed that in polyploid plants the photosynthetic rate per cell is correlated with the amount of DNA per cell; therefore, at higher ploidy levels, higher photosynthetic rates are expected. Furthermore, intersectional hybrids showed higher $\mathrm{CO}_{2}$ exchange rate than their parental species. Laboratory experiments under controlled conditions are required to compare the different clones, and such data could be used to predict performance of poplars in the field (CEULEMANs et al., 1980; IsEBRANDS et al., 1988). However, photosynthesis is a complex trait under polygenic control and these measurements are often instantaneous estimations from individual leaves and could not be representative of the entire day or season (IsEBRANDS et al., 1988), 
are weak (CEulemans et al., 1987) or do not exist for ploidy levels lower than hexaploid (BUNN et al., 2004; WARNER et al., 1993). Hence, this study will examine the hypothesis that biomass and wood quality in poplar clones can be improved through the selection of specific morphological and physiological traits and that an appropriate ploidy level might be an indicator for an early selection. Seasonal trends and their influences on these parameters will also be analysed.

\section{Materials and methods}

\subsection{Plant material}

For this study poplar clones of the Populus section (former Leuce) were chosen, mainly due to their low requirements of soil quality, water supply and tolerance to drought stress. Three clones were obtained from the Thünen-Institut of Forest Genetics, Waldsieversdorf, Germany. Populus tremula sp (clone Brauna 11), Populus tremula $\times$ Populus tremuloides hybrid (clone Esch 5 from combination Brauna 11 x Turesson 141, now defined as sort "Holsatia") and Populus canescens (clone L447) (Table 1) were originated and propagated through tissue culture (EwALD et al., 2009). L 447, a grey poplar (P. tremula $\times$ P. alba), was included because it was better in performance, like aspen and hybrid aspen clones used here. The genotypeenvironment interaction in hybrids is generally less pronounced than in parent species. Therefore, hybrids perform better in different environments compared with parental types.
Three stable subsets of each clone were generated: diploid $(2 \mathrm{~N})$, mixoploid $(2 \mathrm{~N} / 4 \mathrm{~N})$ and tetraploid $(4 \mathrm{~N})$. The mixoploid and tetraploid lines were obtained through in vitro colchicine treatment of shoots tips or meristems of leaf axils using $0.1 \%$ colchicine for 16 hours. This toxic natural product prevents the appropriate distribution of chromosome chromatids by binding to tubulin, one of the main constituents of microtubules, and thereby causes polyploidy in the resulting cells (EWALD et al., 2009). The micropropagated shoot tips were maintained at $23^{\circ} \mathrm{C}$ under a 16 hours photoperiod supplied by warm-white fluorescent light.

Using this method, it was possible to generate a large number of plants, but in the mixoploid lines, although they were stable for more than one year before start the experiments, the ploidy level had to be tested because mixoploid plants could be to a low extent unstable splitting back to diploid or tetraploid individuals (VÄINÖLÄ, 2000). When the plantlets reached an appropriate size, they were planted in commercial propagation soil in individual 2 litre pots. Immediately after transferring the plantlets to the soil, they were inoculated with endophytic bacteria and fungi in commercial powder ("Mycorrhizae soluble" brand from www.myccorhizae.eu) to avoid fungal attacks and diseases (ULRICH et al., 2008) and to increase the absorbing capacity of the roots regarding the water and nutrient supply. The plantlets were placed in a greenhouse under controlled environmental conditions using supplementary light to provide long-day conditions of approximately 12 hours. A flow cytometry analysis was

Table 1. - Studied Poplar materials with name, parental provenances, sex and general features.

\begin{tabular}{|c|c|c|c|c|}
\hline Clone & $\begin{array}{l}\text { Parental or } \\
\text { clonal groups }\end{array}$ & Sex & General features & Abbreviated names \\
\hline $\begin{array}{l}\text { Esch } 5 \text { (trembling } \\
\text { aspen hybrid) }\end{array}$ & $\begin{array}{l}\text { P.tremulax } \\
\text { P.tremuloides }\end{array}$ & Female & $\begin{array}{l}\text { Best-performing } \\
\text { offspring clone of } \\
\text { Brauna } 11 \times \\
\text { Turesson } 141 \\
\text { cross; fast growing, } \\
\text { drought tolerant. }\end{array}$ & $\begin{array}{l}\text { Ed }=\text { Esch } 5 \text { diploid } \\
\text { Em }=\text { Esch } 5 \text { mixoploid } \\
\text { Et }=\text { Esch } 5 \text { tetraploid }\end{array}$ \\
\hline $\begin{array}{l}\text { Brauna11(Trembling } \\
\text { Aspen) }\end{array}$ & P.tremula & Female & $\begin{array}{l}\text { Fast growing, } \\
\text { drought tolerant, } \\
\text { selected female } \\
\text { parent. }\end{array}$ & $\begin{array}{l}\mathrm{Bd}=\text { Brauna } 11 \text { diploid } \\
\mathrm{Bm}=\text { Brauna } 11 \text { mixoploid } \\
\mathrm{Bt}=\text { Brauna } 11 \text { tetraploid }\end{array}$ \\
\hline L 447(Grey poplar) & P.canescens & Female & $\begin{array}{l}\text { Fast growth, low } \\
\text { water } \\
\text { requirements. }\end{array}$ & $\begin{array}{l}\mathrm{Ld}=\mathrm{L} 447 \text { diploid } \\
\mathrm{Lm}=\mathrm{L} 447 \text { mixoploid } \\
\mathrm{Lt}=\mathrm{L} 447 \text { tetraploid }\end{array}$ \\
\hline
\end{tabular}


performed to detect the correct ploidy level in mixoploids and in some tetraploid plants. Mixoploids are a type of chimera that consists of diploid cells $(2 \mathrm{~N})$ and tetraploid cells $(4 \mathrm{~N})$ (KAENSAKSIRI et al., 2011). These tests were carried out twice a year; 1) when the plantlets were growing in tissue culture. 2) after transferring the plantlets to the soil. Nuclei suspensions were prepared from leaf tissues as described by GONZÁLEZ CASTAÑón et al. (2002) using a Partec CyFlow ${ }^{\circledR}$ Ploidy Analyser „DAPI“ (Partec GmbH, Münster, North-Rhine Westfalia, Germany). By comparing the samples to a known diploid standard, the ploidy level was determined (WANG et al., 2014). After 12 weeks, the plants were relocated to another greenhouse in ZALF (Leibniz Center for Agricultural Landscape Research, Müncheberg, Germany), where measurements were performed. Thirty plants of each clone (10 per ploidy level) were selected for gas exchange measurements. The plants were well watered during the experimental period.

\subsection{Gas exchange measurements}

Gas exchange was measured in the $1^{\text {st }}$ fully expanded leaf of each plant. The measurements were performed in a climate-controlled chamber under normalised conditions $\left(21^{\circ} \mathrm{C}, 60-65 \%\right.$ R.H. or $15^{\circ} \mathrm{C}, 85 \%$ R.H. during the day or night, respectively) using a portable open gas exchange system (HCM-1000, Walz, Effeltrich, Bavaria, Germany). During the measuring period, the photosynthetically active radiation (PhAR) was increased in daily increments, where each light intensity stage was maintained for an entire day. The level of light in the cuvette and the climate chamber was increased from zero (dark respiration) to $1000 \mu \mathrm{mol}$ quanta $/ \mathrm{m}^{2} \mathrm{~s}$. The following levels were used: $0,50,120,200,300,500,750$, and 900 or 1000 umol quanta $/ \mathrm{m}^{2} \mathrm{~s}$. This procedure was used to measure the light response of net photosynthesis (A). The temperature and relative humidity in the gas exchange cuvette were held constant at $21^{\circ} \mathrm{C}$ and $60-65 \%$, respectively. Consequently, each experiment was performed over 7-8 days in a set of 10 plants per clone. The measuring of the 90 plants per light step required 10 hours per day. To avoid systematic errors due to different sensibilities during the daytime, the time sequence was randomly planned to ensure that diurnal changes in carbohydrate status were minimal. This measure- ment procedure was repeated 3 times during the season, approximately every 6 weeks.

\subsection{Biometric measurements}

Plant height was measured every two weeks to describe the ontogenetic development of plant growth. In September, the specific leaf area (SLA) of a sub-set of 18 plants was calculated as the quotient of the leaf area (LA) and dry mass $\left(65^{\circ} \mathrm{C}\right.$ over 24 hours). The LA was determined using a mobile handheld scanner (Scandoo SD, dnt-GmbH, Dietzenbach, Hesse, Germany) and the open access software Lafore (V. Lehsten, Oldenburg University, Lower Saxony, Germany). The leaves that fell during the season were collected, dried and weighed. The whole biomass was harvested in September and biometric analysis of the woody parts was performed. The maximal diameters and lengths were determined. The wood was then dried at $105^{\circ} \mathrm{C}$ during 24 hours and weighed with bark. The wood volume of each of the 90 trees was calculated using the frustum formula, the wood dry mass was determined and the density of the dry wood was calculated from the dry mass and the wood volume.

\subsection{Calculations and statistical analysis}

Based on the measured parameters, the net photosynthesis (A), transpiration rate (E) and vapour pressure deficit $\left(\mathrm{VPD}_{\text {leaf }}\right)$ were determined according to CAEMMERER and FARQUHAR (1981), and the stomatal conductance $\left(\mathrm{g}_{\mathrm{S}}\right)$ and intrinsic water-use efficiency $\left(\mathrm{WUE}_{\text {intr }}\right)$ were calculated according to FARQUHAR et al. (1989) and TAMBUSSI et al. (2007).

The obtained light response curves were fitted to a non-linear exponential model (WEBB et al., 1974, modified by SCHUlte et al., 2003) using Excel Solver:

$$
A=f(I)=a-\exp (b(-I)) c
$$

where $\mathrm{A}$ is the net $\mathrm{CO}_{2}$ exchange rate $(\mu \mathrm{mol}$ $\mathrm{CO}_{2} / \mathrm{m}^{2} \mathrm{~s}$ ) and $\mathrm{I}$ is the applied PhAR ( $\mathrm{umol}$ quanta $/ \mathrm{m}^{2} \mathrm{~s}$ ). The variable parameters $\mathrm{a}, \mathrm{b}$ and $\mathrm{c}$ are values to specify the light response curve, at which $\mathrm{a}$ is the maximal photosynthesis $\left(\mathrm{A}_{\max }\right)$ and a-c is represent dark respiration. Furthermore, the following parameters can be derived:

- Light Saturation Point $\left(\mathrm{I}_{\mathrm{S}}\right) \quad(\mu \mathrm{mol}$ quanta $\left./ \mathrm{m}^{2} \mathrm{~s}\right)=\ln (0.1 \mathrm{a} / \mathrm{c})(-1 / \mathrm{b})$ describes the light value at $90 \%$ of $A_{\max }$. 

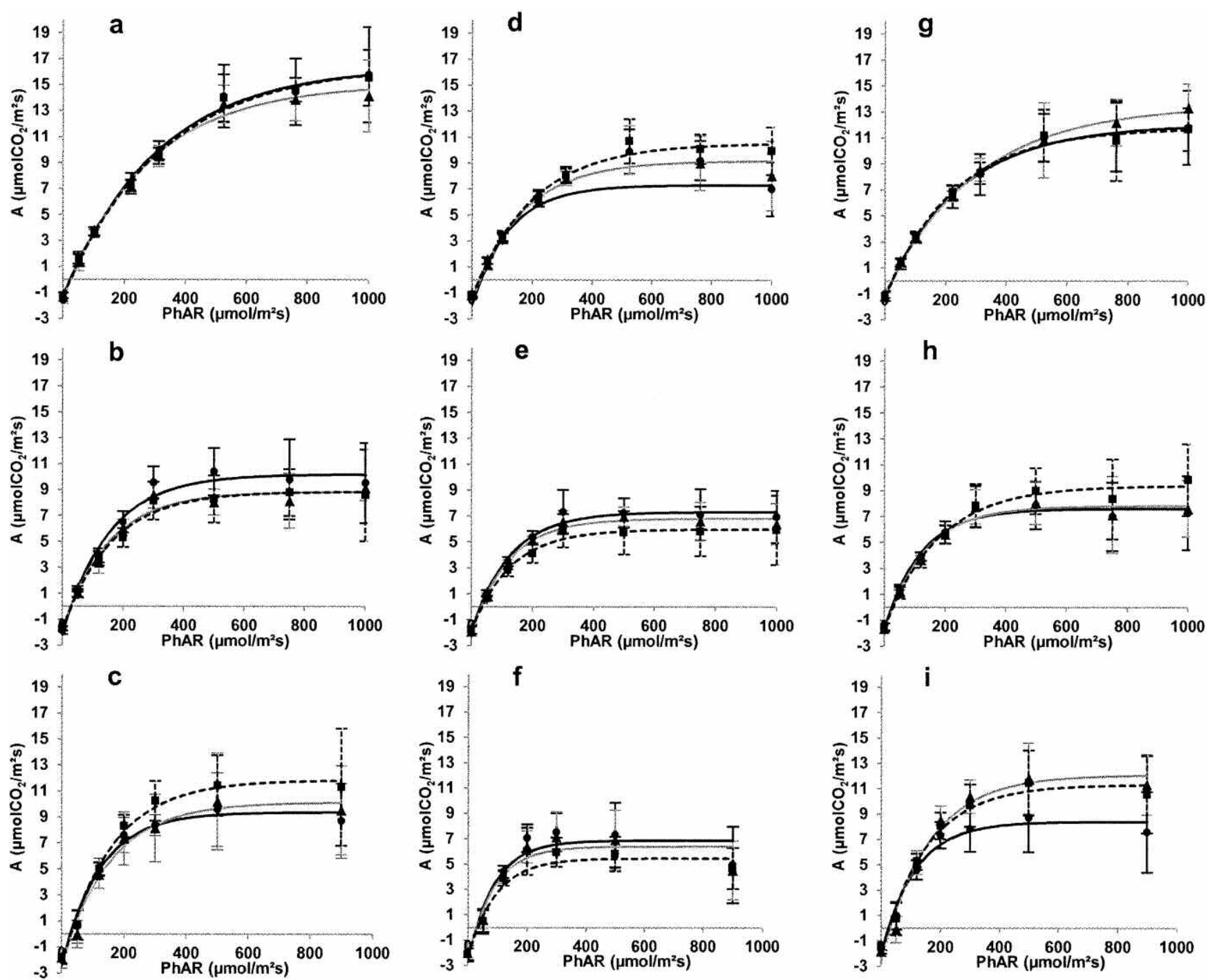

Figure 1. - Light response of photosynthesis (A) in the young fully developed leaves of three poplar clones of different ploidies; a, b, c: Brauna 11 light response curves for May, July and September, respectively; d, e, f: L447 light response curves for May, July and September, respectively; $\mathbf{g}$, h, i: Esch 5 light response curves for May, July and September, respectively; (diploid - circles and black lines, mixoploid - triangles and grey lines, tetraploid - squares and dotted lines) during the growing season (May, July and September). Regression lines based on Schulte et al. (2003). Mean values $( \pm S D)$. Temperature $=21^{\circ} \mathrm{C}$, relative humidity $=65 \%, \mathrm{n}=10$.

- Light Compensation Point $\left(\mathrm{I}_{0}\right) \quad($ umol quanta $\left./ \mathrm{m}^{2} \mathrm{~s}\right)=\ln (\mathrm{a} / \mathrm{c})(-1 / \mathrm{b})$ the light value at which gross photosynthesis is compensated by respiration.

A factorial ANOVA was used to assess statistically significant effects of the species, ploidy level and species $\times$ ploidy level interactions on the photosynthetic parameters and growth performance. When the main effects were significant, or when interactions were detected, post hoc tests were performed using Tukey's Multiple Range Test or the Newman-Keuls test. The differences were tested at probability levels of $p=0.05,0.01$ and lower values. Linear correlations between different parameters were also carried out by Pearson's coefficient tests. All statistics were calculated using the statistical software NCSS (Kaysville, Utah, USA) and the mathematical programme Mathematica 8.0 distributed by Wolfran (Hamborough, Oxfordshire,UK). 


\section{Results}

\subsection{Ploidy level tests}

The flow cytometry analysis showed that approximately $5 \%$ of the total mixoploids became diploids or tetraploids. The plants that showed an incorrect ploidy level were discarded and replaced. Therefore, this analysis is justified, although it is timeconsuming and expensive.

\subsection{Net $\mathrm{CO}_{2}$ gas exchange rates}

Variations in net photosynthesis (A) due to the season were detected; the results for all clones in May were higher than those in July and September (Fig. 1). Seasonality was the strongest influencing factor, while only a few significant differences were caused by the ploidy level (Table 2).

In May, the three tree clones differed significantly. Brauna 11 was the most productive clone (Fig. 1a), with net photosynthesis (A) peaking at approximately $15 \mu \mathrm{mol} \mathrm{CO}_{2} / \mathrm{m}^{2} \mathrm{~s}$, followed by Esch 5 (up to $12 \mu \mathrm{mol} \mathrm{CO}_{2} / \mathrm{m}^{2} \mathrm{~s}$, see Fig. 1 ). L447 displayed the lowest A, showing values of approximately $9-10 \mu \mathrm{mol} \mathrm{CO}_{2} / \mathrm{m}^{2} \mathrm{~s}$ at $500 \mathrm{PhAR}$, which decreased at higher light intensities (Fig. 1d). The photosynthetic rates decreased in all clones in the middle of the growing period compared with the previous measurements. In July, the photosynthesis of the clones differed significantly, and influences of the ploidy level were found at low light intensities (50-300 PhAR) (Table 2). The values were lower than in May for all 9 variants, with Brauna diploid ( $\mathrm{Bd}$ ) exhibiting the highest net photosynthesis of up to $10.4 \mu \mathrm{mol} \mathrm{CO}_{2} / \mathrm{m}^{2} \mathrm{~s}$ at $500 \mathrm{PhAR}$ (Fig. 1b), which then decreased under higher light conditions. Differences between Esch 5 and Brauna 11 were significant only in some single light steps, but differences of both clones with L 447 were detected (Table 2 ). There were significant differences between the diploid Brauna 11 and its mixoploid and tetraploid lines (Figure 1b). The mixoploid and tetraploid lines of L447 showed the lowest values among the 9 variants throughout the entire measurement period. The last measurements were obtained in September, very close to the time of senescence. Compared with previous measurements, a slight increase in net photosynthesis was observed in all of the Esch and Brauna clones except $\mathrm{Bd}$, whereas an increase was not observed not in the L447 lines. This increase occurred in a different manner for each isogenic line. There was a clear effect of clone, but no effect of the ploidy level was detected.

Table 2. - Multiple ANOVA for photosynthesis (A) during the growing period. Different letters in the same rows indicate significant differences at $\mathrm{p} \leq 0.05$, determined through Tukey-Kramer post hoc analysis.

\begin{tabular}{|c|c|c|c|c|c|c|c|}
\hline & $\mathrm{PhAR}\left(\mu \mathrm{mol} / \mathrm{m}^{2} \mathrm{~s}\right)$ & Braunall & $\mathrm{L} 447$ & Esch5 & Diploid & Mixoploid & Tetraploid \\
\hline \multirow{8}{*}{$\stackrel{\gtrsim}{\Sigma}$} & 1000 & $\mathrm{c}$ & $\mathrm{a}$ & $\mathrm{b}$ & a & $\mathrm{a}$ & a \\
\hline & 750 & c & a & $\mathrm{b}$ & $\mathrm{a}$ & a & $\mathrm{a}$ \\
\hline & 500 & $b$ & a & $\mathrm{a}$ & a & a & a \\
\hline & 300 & b & a & $\mathrm{a}$ & a & a & a \\
\hline & 200 & $c$ & a & $\mathrm{b}$ & a & a & a \\
\hline & 100 & b & a & $\mathrm{a}$ & a & a & a \\
\hline & 50 & a & a & a & a & a & a \\
\hline & 0 & a & $\mathrm{a}$ & $\mathrm{a}$ & a & a & $\mathrm{a}$ \\
\hline \multirow{8}{*}{$\geqq$} & 1000 & $\mathrm{~b}$ & $\mathrm{a}$ & $\mathrm{b}$ & a & $\mathrm{a}$ & $\mathrm{a}$ \\
\hline & 750 & b & a & $\mathrm{a}$ & a & a & $\mathrm{a}$ \\
\hline & 500 & b & a & $\mathrm{b}$ & a & $a$ & a \\
\hline & 300 & $\mathrm{c}$ & a & $\mathrm{b}$ & b & $a b$ & $\mathrm{a}$ \\
\hline & 200 & $\mathrm{~b}$ & a & $\mathrm{b}$ & b & $\mathrm{b}$ & $\mathrm{a}$ \\
\hline & 120 & b & a & $\mathrm{b}$ & $\mathrm{b}$ & a & a \\
\hline & 50 & b & a & $\mathrm{b}$ & b & a & a \\
\hline & 0 & b & $\mathrm{a}$ & $\mathrm{b}$ & $\mathrm{a}$ & a & $\mathrm{a}$ \\
\hline \multirow{7}{*}{$\begin{array}{l}\frac{1}{D} \\
\text { E } \\
\frac{D}{0} \\
\frac{0}{D} \\
\tilde{D}\end{array}$} & 900 & $\mathrm{~b}$ & $\mathrm{a}$ & $\mathrm{b}$ & $\mathrm{a}$ & a & $\mathrm{a}$ \\
\hline & 500 & b & a & b & a & a & a \\
\hline & 300 & b & a & b & $\mathrm{a}$ & a & $\mathrm{a}$ \\
\hline & 200 & b & a & $\mathrm{b}$ & a & a & a \\
\hline & 120 & b & a & b & a & a & a \\
\hline & 50 & a & $\mathrm{a}$ & $\mathrm{a}$ & a & a & $\mathrm{a}$ \\
\hline & 0 & b & $\mathrm{a}$ & $\mathrm{a}$ & $\mathrm{a}$ & $\mathrm{a}$ & a \\
\hline
\end{tabular}



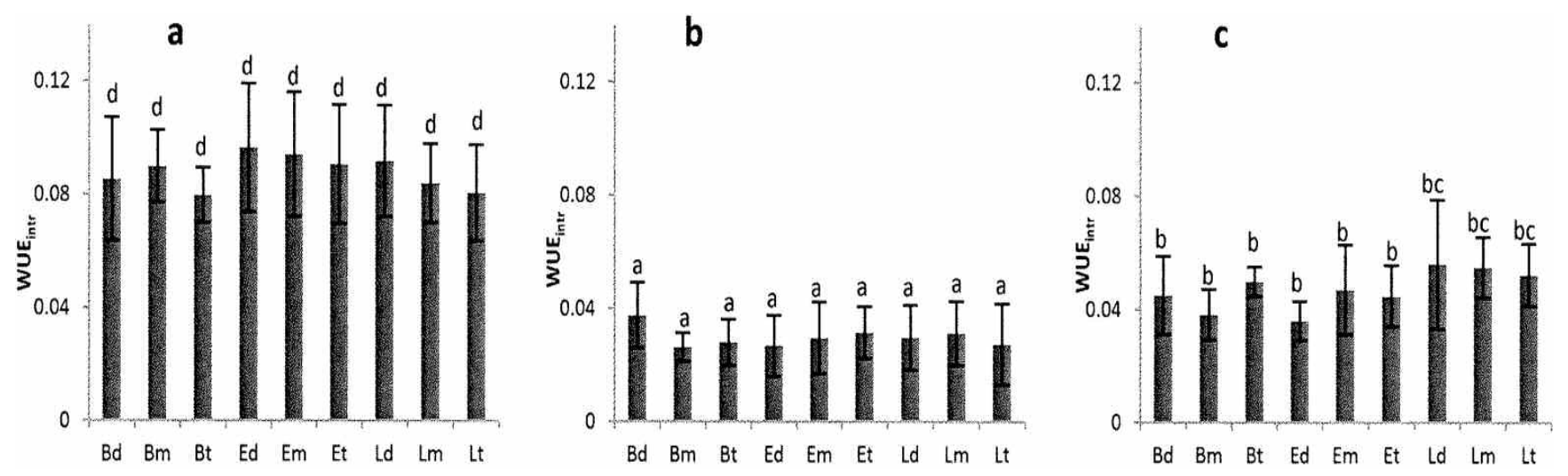

Figure 2. - $\mathrm{WUE}_{\text {intr }}$ under saturated light (500 PhAR) during the growing season. a, b, c: measurements collected in May, July and September, respectively. Mean values $( \pm S D$ ). The bars with different letters are significantly different at $\mathrm{p} \leq 0.05$, determined through Tukey-Kramer post hoc analysis. Temperature $=21^{\circ} \mathrm{C}$, relative humidity $=65 \%, \mathrm{n}=10$.

a

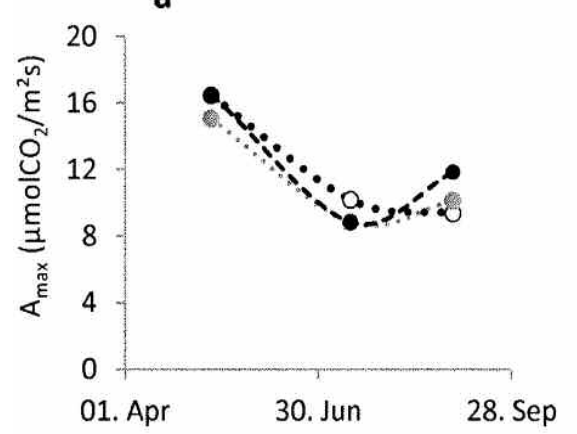

b

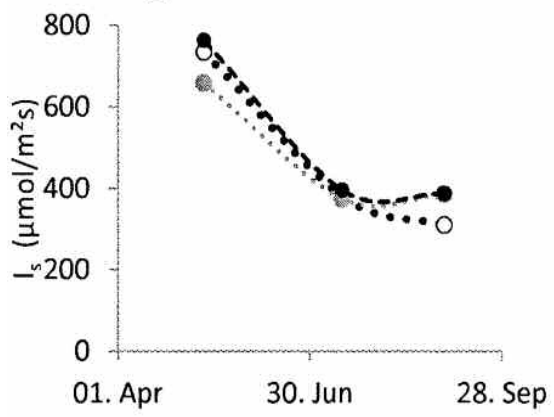

c

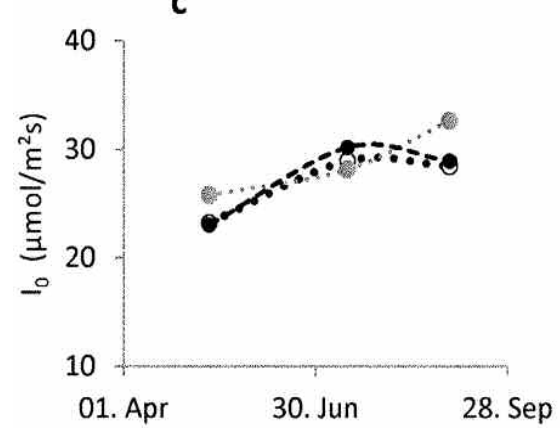

d

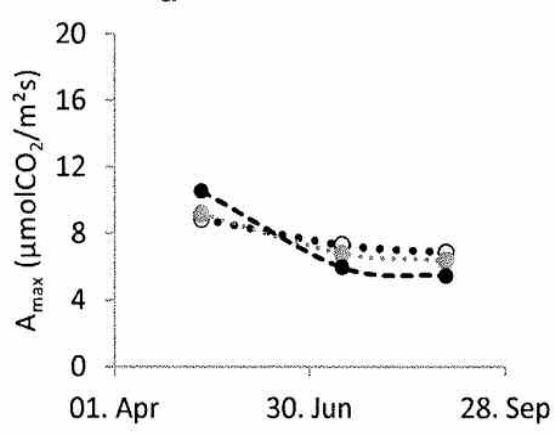

e

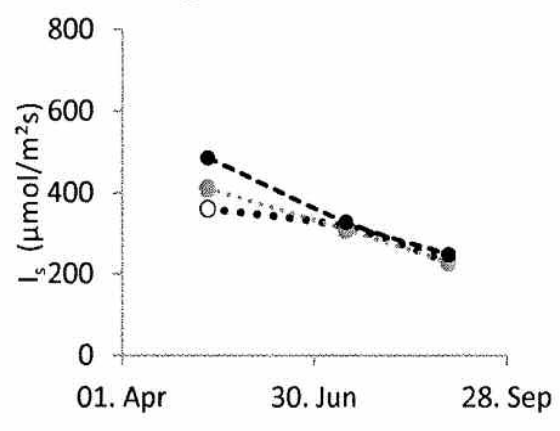

f

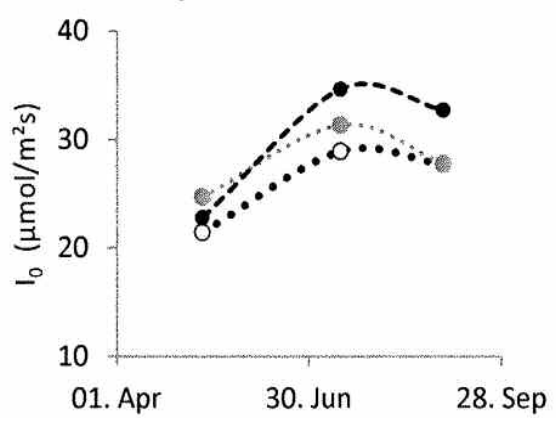

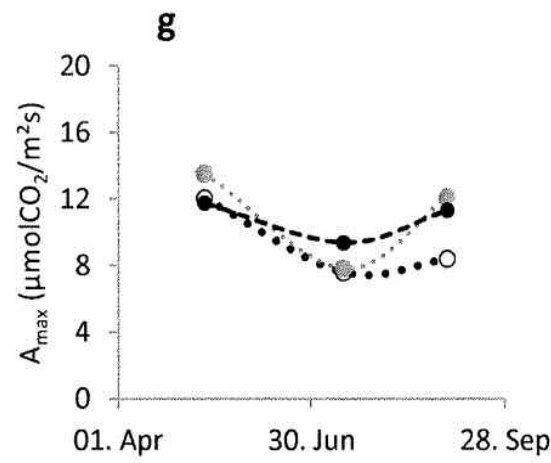

h

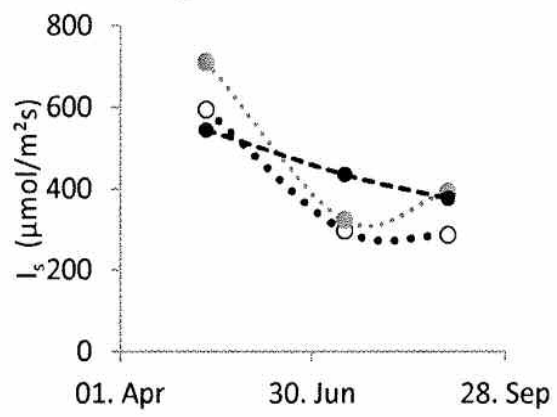

i

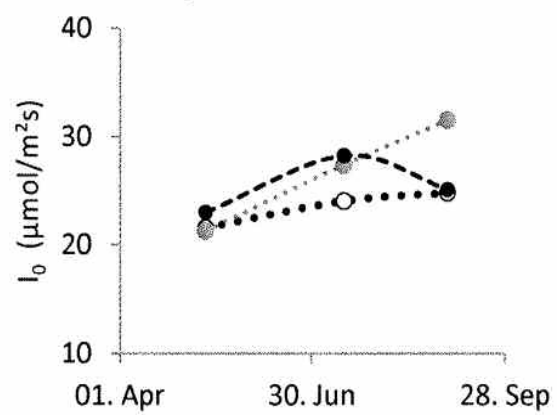

Figure 3. - Seasonal evolution of net photosynthesis $\left(\mathrm{A}_{\max }\right)$, the light saturation point $\left(\mathrm{I}_{\mathrm{S}}\right)$ and the light compensation point $\left(\mathrm{I}_{0}\right)$ in the clones Brauna 11 (a, b, c, respectively), L447 (d, e, f) and Esch5 (g, h, i). Empty circles, diploid isogenic line. Grey circles, mixoploid isogenic line. Bold circles, tetraploid isogenic line. The values were obtained from the model created by WeBB et al. (1974), as modified and supplemented by SchULte et al. (2003). 


\subsection{WUE intrinsic at $500 \mathrm{PhAR}$}

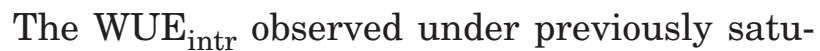
rated light (500 $\mathrm{PhAR}$ ) oscillated greatly during the growing season (Fig. 2) and same trend as in A was detected. The effect of the season in which the measurements were collected was significant. Higher values were obtained in May, but all of the clones were within the same range (Fig. 2a). From May to July, there was a substantial decrease of more than $50 \%$, and once again, none of the clones showed significant differences (Fig. 2b). In September, an increase in the $\mathrm{WUE}_{\text {intr }}$ was detected compared with the results for July, but the clones still failed to reach the values they presented in May.

In general, there were no significant effects of the ploidy level or the clone. In the range of 0-600 PhAR, L447 was the most water-efficient clone, while under high light intensities, Esch5 was the most water-efficient clone.

\subsection{Maximal Photosynthesis $\left(A_{\max }\right)$,}

Light saturation point $\left(I_{S}\right)$, Light compensation point $\left(I_{0}\right)$

The parameters that were derived from the model are shown in Figure 3. Similar trends were found in the analyses of $\mathrm{I}_{\mathrm{S}}$ and $\mathrm{A}_{\max }$. The maximal photosynthesis varied in all clones during the different measurements in the season. In May, Brauna 11 exhibited the highest $\mathrm{A}_{\max }$; its 3 isogenic lines presented values varying between 15 and $16.5 \mu \mathrm{mol} \mathrm{CO}_{2} / \mathrm{m}^{2} \mathrm{~s}$, with the tetraploid line showing the highest value (Fig. 3a). The next highest values were found for Esch 5 (Em), which showed a decrease of $15 \%$ compared with Brauna. L447 presented the lowest $A_{\max }$. In July, the 9 variants exhibited decreased values compared with May, with the largest decrease observed in Brauna 11 $(40 \%)$. At the end of the growing season, minor increases were identified in almost all of the Brauna 11 and Esch 5 lines and decreases in $\mathrm{Bd}$ and all lines of L 447 (Fig. 3a, $d, g$ ).

Seasonal changes in $\mathrm{I}_{\mathrm{S}}$ were also observed in all of the isogenic lines. Under early spring conditions (May), the highest $I_{S}$ values were found in Brauna 11, while the diploid line of L447 exhibited the lowest $\mathrm{I}_{\mathrm{S}}$ value (Fig. $\left.3 b, e, h\right)$. In early summer (July), all of the variants showed a decreased $\mathrm{I}_{\mathrm{S}}$. During late summer, an increase in $\mathrm{I}_{\mathrm{S}}$ was found, but not in all variants. In May, Pearson's coefficient for $\mathrm{A}_{\max }$ and $\mathrm{I}_{\mathrm{S}}$ with height for all lines (90 plants) was negative and strong $(\mathrm{r}=-0.88$ and -0.81 , respectively). Light compensation points $\left(\mathrm{I}_{0}\right)$ were detected between 20 and $33 \mu \mathrm{mol}$ quantum $/ \mathrm{m}^{2} \mathrm{~s}$ for all of the clones during the seasons (Fig. 3c, $f, i$ ).

\subsection{Biometric parameters}

Data concerning total plant biomass are shown in Table 3. There were significant differences between both clones and ploidy levels, and a clone $\mathrm{x}$ ploidy level interaction was detected. The trees produced a mean leaf dry mass of 13.7 to $18.8 \mathrm{~g}$, with the greatest leaf

Table 3. - Wood and leaf parameters. The material was harvested at the end of the growing period and then dried at $105^{\circ} \mathrm{C}$ for 48 hours. Different letters in the same row indicate significant differences at $\mathrm{p} \leq 0.05$ determined through Tukey-Kramer post hoc analysis. Leaf mass; $n=10$, specific leaf area, leaf area, wood parameters; $n=2$.

\begin{tabular}{|c|c|c|c|c|c|c|c|c|c|}
\hline $\begin{array}{l}\text { Means per tree } \\
(\mathrm{n}=10)\end{array}$ & $\begin{array}{l}\text { Brauna } \\
\text { diploid }\end{array}$ & $\begin{array}{l}\text { Brauna } \\
\text { mixoploid }\end{array}$ & $\begin{array}{l}\text { Brauna } \\
\text { tetraploid }\end{array}$ & $\begin{array}{l}\text { L447 } \\
\text { diploid }\end{array}$ & $\begin{array}{l}\text { L447 } \\
\text { mixoploid }\end{array}$ & $\begin{array}{l}\text { L447 } \\
\text { tetraploid }\end{array}$ & $\begin{array}{l}\text { Esch } 5 \\
\text { diploid }\end{array}$ & $\begin{array}{l}\text { Esch } 5 \\
\text { mixoploid }\end{array}$ & $\begin{array}{l}\text { Esch } 5 \\
\text { tetraploid }\end{array}$ \\
\hline Leaf mass $(\mathrm{g})$ & $14.6^{\mathrm{a}}$ & $15.3^{\mathrm{ab}}$ & $15.8^{\mathrm{ab}}$ & $17.2^{\mathrm{abc}}$ & $17.4^{b c}$ & $17.5^{\mathrm{bc}}$ & $13.7^{\mathrm{ab}}$ & $17.2^{\mathrm{b}}$ & $18.8^{\mathrm{C}}$ \\
\hline $\begin{array}{l}\text { Specific Leaf } \\
\text { Area }\left(\mathrm{cm}^{2} / \mathrm{g}\right)\end{array}$ & $209.2^{\mathrm{ab}}$ & $202^{\mathrm{a}}$ & $210.3^{\mathrm{ab}}$ & $167.1^{\mathrm{a}}$ & $171.2^{\mathrm{a}}$ & $147^{\mathrm{a}}$ & $231.4^{\mathrm{ab}}$ & $190.1^{\mathrm{ab}}$ & $211.8^{\mathrm{ab}}$ \\
\hline Leaf Area $\left(\mathrm{cm}^{2}\right)$ & $3010^{\mathrm{a}}$ & $3132^{\mathrm{ab}}$ & $3571^{\mathrm{b}}$ & $3056^{\mathrm{a}}$ & $3049^{\mathrm{ab}}$ & $2518^{a}$ & $3209^{\mathrm{ab}}$ & $3324^{b}$ & $4089^{c}$ \\
\hline Wood mass (g) & $18^{\mathrm{ab}}$ & $16.6^{\mathrm{ab}}$ & $12.5^{\mathrm{a}}$ & $21.5^{\mathrm{b}}$ & $21.1^{\mathrm{b}}$ & $20.3^{\mathrm{ab}}$ & $19.6^{\mathrm{ab}}$ & $22.9^{\mathrm{b}}$ & $20.7^{\mathrm{ab}}$ \\
\hline $\begin{array}{l}\text { Wood volume } \\
\left(\mathrm{cm}^{3}\right)\end{array}$ & $42.4^{\mathrm{a}}$ & $38.5^{\mathrm{a}}$ & $31.4^{\mathrm{a}}$ & $49.7^{\mathrm{ab}}$ & $48.2^{\mathrm{ab}}$ & $51^{\mathrm{ab}}$ & $49.5^{\mathrm{ab}}$ & $56.7^{\mathrm{ab}}$ & $53.6^{\mathrm{ab}}$ \\
\hline $\begin{array}{l}\text { Wood density } \\
\left(\mathrm{g} / \mathrm{cm}^{3}\right)\end{array}$ & $0.428^{\mathrm{b}}$ & $0.432^{\mathrm{b}}$ & $0.400^{\mathrm{ab}}$ & $0.436^{\mathrm{b}}$ & $0.440^{\mathrm{b}}$ & $0.400^{\mathrm{ab}}$ & $0.400^{\mathrm{ab}}$ & $0.404^{\mathrm{ab}}$ & $0.389^{\mathrm{a}}$ \\
\hline
\end{tabular}


Table 4. - Height evolution during the growing period $(\mathrm{mm})$. Significance levels of the analysed parameters: $* \mathrm{p}<0.05, * * \mathrm{p}<0.01, * * * \mathrm{p}<0.001,0=\mathrm{p}>0.5$, Different letters in the same row indicate significant differences at $\mathrm{p} \leq 0.05$ determined through Tukey-Kramer post hoc analysis.

\begin{tabular}{ccccccccccccc}
\hline Days in soil & Specie & Ploidy & $\mathrm{S} \mathrm{x} \mathrm{P}$ & $\mathrm{Bd}$ & $\mathrm{Bm}$ & $\mathrm{Bt}$ & $\mathrm{Ld}$ & $\mathrm{Lm}$ & $\mathrm{Lt}$ & $\mathrm{Ed}$ & $\mathrm{Em}$ & $\mathrm{Et}$ \\
\hline 18 & $* * *$ & $* * *$ & $*$ & $51^{\mathrm{ab}}$ & $42^{\mathrm{ab}}$ & $32^{\mathrm{a}}$ & $74^{\mathrm{bc}}$ & $71^{\mathrm{bc}}$ & $55^{\mathrm{abc}}$ & $50^{\mathrm{b}}$ & $48^{\mathrm{b}}$ & $45^{\mathrm{ab}}$ \\
52 & $* * *$ & $* * *$ & $*$ & $198^{\mathrm{ab}}$ & $173^{\mathrm{ab}}$ & $124^{\mathrm{a}}$ & $292^{\mathrm{bc}}$ & $317^{\mathrm{bc}}$ & $279^{\mathrm{abc}}$ & $230^{\mathrm{b}}$ & $217^{\mathrm{b}}$ & $216^{\mathrm{ab}}$ \\
61 & $* * *$ & $* * *$ & $*$ & $249^{\mathrm{ab}}$ & $226^{\mathrm{ab}}$ & $155^{\mathrm{a}}$ & $341^{\mathrm{bc}}$ & $377^{\mathrm{bc}}$ & $322^{\mathrm{abc}}$ & $318^{\mathrm{b}}$ & $291^{\mathrm{b}}$ & $264^{\mathrm{ab}}$ \\
74 & $* * *$ & $* * *$ & 0 & $360^{\mathrm{ab}}$ & $332^{\mathrm{ab}}$ & $168^{\mathrm{a}}$ & $487^{\mathrm{bc}}$ & $514^{\mathrm{bc}}$ & $396^{\mathrm{abc}}$ & $465^{\mathrm{b}}$ & $448^{\mathrm{b}}$ & $339^{\mathrm{ab}}$ \\
88 & $* * *$ & $* * *$ & 0 & $360^{\mathrm{ab}}$ & $390^{\mathrm{ab}}$ & $174^{\mathrm{a}}$ & $521^{\mathrm{b}}$ & $536^{\mathrm{b}}$ & $421^{\mathrm{ab}}$ & $571^{\mathrm{b}}$ & $515^{\mathrm{b}}$ & $377^{\mathrm{ab}}$ \\
96 & $* * *$ & $* * *$ & $*$ & $516^{\mathrm{ab}}$ & $563^{\mathrm{ab}}$ & $252^{\mathrm{a}}$ & $621^{\mathrm{b}}$ & $628^{\mathrm{b}}$ & $516^{\mathrm{ab}}$ & $702^{\mathrm{b}}$ & $613^{\mathrm{b}}$ & $453^{\mathrm{ab}}$ \\
102 & $* * *$ & $* * *$ & 0 & $741^{\mathrm{ab}}$ & $730^{\mathrm{ab}}$ & $464^{\mathrm{a}}$ & $793^{\mathrm{b}}$ & $822^{\mathrm{b}}$ & $682^{\mathrm{ab}}$ & $834^{\mathrm{b}}$ & $779^{\mathrm{b}}$ & $636^{\mathrm{ab}}$ \\
111 & $* * *$ & $* * *$ & $* *$ & $990^{\mathrm{ab}}$ & $975^{\mathrm{ab}}$ & $743^{\mathrm{a}}$ & $1001^{\mathrm{b}}$ & $1048^{\mathrm{b}}$ & $935^{\mathrm{ab}}$ & $1023^{\mathrm{b}}$ & $964^{\mathrm{b}}$ & $896^{\mathrm{ab}}$ \\
119 & 0 & $* * *$ & 0 & $1158^{\mathrm{ab}}$ & $1219^{\mathrm{ab}}$ & $950^{\mathrm{a}}$ & $1189^{\mathrm{ab}}$ & $1210^{\mathrm{ab}}$ & $1076^{\mathrm{a}}$ & $1167^{\mathrm{ab}}$ & $1155^{\mathrm{ab}}$ & $1033^{\mathrm{a}}$ \\
129 & 0 & $* * *$ & $* *$ & $1413^{\mathrm{ab}}$ & $1452^{\mathrm{ab}}$ & $1157^{\mathrm{a}}$ & $1409^{\mathrm{ab}}$ & $1428^{\mathrm{ab}}$ & $1293^{\mathrm{a}}$ & $1346^{\mathrm{ab}}$ & $1364^{\mathrm{ab}}$ & $1287^{\mathrm{a}}$ \\
153 & 0 & $* * *$ & $* *$ & $1452^{\mathrm{ab}}$ & $1484^{\mathrm{ab}}$ & $1197^{\mathrm{a}}$ & $1459^{\mathrm{ab}}$ & $1468^{\mathrm{ab}}$ & $1344^{\mathrm{a}}$ & $1407^{\mathrm{ab}}$ & $1450^{\mathrm{ab}}$ & $1299^{\mathrm{a}}$ \\
173 & 0 & $* * *$ & $*$ & $1453^{\mathrm{ab}}$ & $1484^{\mathrm{ab}}$ & $1197^{\mathrm{a}}$ & $1460^{\mathrm{ab}}$ & $1470^{\mathrm{ab}}$ & $1349^{\mathrm{a}}$ & $1407^{\mathrm{ab}}$ & $1452^{\mathrm{ab}}$ & $1304^{\mathrm{a}}$ \\
\hline
\end{tabular}

mass produced by the tetraploid line, followed by the mixoploid and diploid lines within each clone. The whole-plant leaf area was highest for the Esch5 tetraploid (Et) $\left(4089 \mathrm{~cm}^{2}\right)$ and lowest for the L447 tetraploid (Lt) $\left(2518 \mathrm{~cm}^{2}\right)$. The lowest specific leaf area was found for the L447 lines, which presented a decrease of more than one-third compared with Brauna 11 and Esch 5. Significant positive correlations of the harvested SLA and LA with the $\mathrm{WUE}_{\text {intr }}$ in all groups (90 plants) were observed at $500 \mathrm{PhAR}$ in September $(\mathrm{r}=0.78$ and 0.3 , respectively) and of the SLA and LA with A at $500 \mathrm{PhAR}$ $(\mathrm{r}=0.70$ and 0.78 , respectively).

The wood mass ranged between $12.5 \mathrm{~g}$ and $22.9 \mathrm{~g}$, for Bt and Em, respectively, and was significantly different between clones as well as ploidy levels. The wood volume was significantly different: the highest value was observed in the mixoploid line of Esch $5\left(56.7 \mathrm{~cm}^{3}\right)$, whereas the lowest value was observed in the tetraploid line of Brauna $11\left(31.4 \mathrm{~cm}^{3}\right)$.

The wood density is one of the most important criteria for the categorisation of wood and fibre quality. Significant influences of the clones and ploidy levels on this parameter were detected. All mixoploid lines tended to have the highest wood densities within each clone. The highest range of wood densities was obtained in L447, despite its low photosynthetic rate.

L447 exhibited the highest growth, followed by Esch5 and Brauna 11. During the first part of the growth period ( $\approx 100$ days in soil), the height of the plants differed and was significantly influenced by the clone as well by the ploidy level (Table 4). The mixoploid and diploid lines of all clones showed similar values, with the mixoploid lines being slightly taller and the tetraploid lines being the shortest. From the end of July to the final harvest, growth stopped in all of the clones $(\approx 130$ days in soil).

\section{Discussion}

Ploidy breeding of Populus through tissue culture methods (using colchicine) permits the treatment of large quantities of clonal shoot tips and the selection of tetraploids in vitro to generate and select new plant material for biomass production (EwALD et al., 2009). The collaboration between tree genetics and physiology provides attractive challenges for the breeding of selected polyploids showing rapid growth and resistance to the changing conditions (CEULEMANS et al., 1990; KARAČIĆ and WEIH, 2006). Increases in photosynthesis to obtain a higher harvest yield might be accomplished by manipulating the crown shape and structure, leaf display or photosynthetic efficiency (LARSON et al., 1969) and by selecting the appropriate ploidy level (QI et al., 2010; LAVANIA; 2005, XU et al., 2014). In this study, the European aspen clone Brauna 11 was the most productive clone in terms of photosynthesis, followed by the aspen hybrid Esch 5, with the grey poplar L447 show- 
ing significantly lower photosynthesis. However, no remarkable influence of the ploidy level was detected.

TAMBUSSI et al. (2007) declared that a high WUE $_{\text {intr }}$ can be achieved either through lower stomatal conductance, a higher photosynthetic capacity or a combination of both. BACON et al. (2004) and QI et al. (2010) reported that there is a tendency for WUE to decrease with increasing productivity, which was confirmed in the present study by the results for Esch 5 and Brauna 11. Therefore, growing clones with high wateruse efficiency under well-watered field cultivation may be detrimental for productivity. Thus, under drought conditions, L447 would have an advantage. In our study, WUE was investigated under well-watered conditions. Under drought conditions, however, $g_{\mathrm{s}}$ is expected to decreased. Thus, photosynthesis and WUE would be altered to a different extent in each individual clone, and the ranking of the efficiency would also presumably change. Additional experiments are needed to clarify this process.

Gas exchange measurements were distributed throughout the day (time randomisation) to avoid systematic influences of diurnal variation (MichAEL, 1990). The gas exchange values showed a wide range, therefore, low significance levels among the clones and ploidy levels were obtained. LAWLOR (1995) and BUNN et al. (2004) suggested that the photosynthetic fixation per unit leaf is often poorly correlated with enhanced yields in breeding programmes because it is difficult to identify the rate-limiting steps within photosynthetic metabolism. Although there is some evidence that leaf-level photosynthetic characteristics may be of value, the development of the leaf area is a better integrated indicator of yield, as shown in previous studies in poplar (BUNN et al., 2004; QI et al., 2010) and in other herbaceous species (XU et al. 2014; WANG et al. 2014). The strong correlations between the physiological measurements performed in this study (A and $\mathrm{WUE}_{\text {intr }}$ at 500 $\mathrm{PhAR}$ ) with LA as well as with the SLA confirm the hypothesis that biometric traits, as main parameters, would be suitable indicators for breeding selection due to the significant variation among ploidy levels within each clone. These parameters, combined with $\mathrm{WUE}_{\text {intr }}$ measurements, into which photosynthetic measurements are integrated, might predict the performance of poplar regarding field growth and biomass production. A review by PoorTER et al. (2009) analysed the variations in leaf mass per area (LMA) under experimental and field conditions relative to several environmental factors. They identified LMA as an important component of plant strategies, and in many cases, this parameter was a good predictor of plant performance.

In this work, L447 displayed a lower and stable $\mathrm{I}_{\mathrm{S}}$ and $\mathrm{A}_{\max }$ during the growing period. The maximum photosynthesis was frequently observed at intermediate PhAR levels, and it decreased at higher radiation intensity in association with a strong decline in gs (stomata closure). This is indicative of the low adaptability of L447 plants to high light intensity. These findings support the idea that L447 behaves like a shade species, as plants that occupy shaded habitats are incapable of high photosynthetic rates but perform efficiently under low light intensities (BOARDMAN, 1977). This allows this clone to be more efficient at seasons with a natural lower light intensity (early spring, early autumn). However, the classification of plants into sun and shade species cannot be performed based on light saturation curves or light compensation points alone, but rather depends on their adaptability to a selected light intensity; consequently, light response curves were generated after 2 to 10 hours of light adaptation. The current efficiency of the plant clones can therefore be compared in leaves under standardised conditions at a fixed time. However, the morphology and physiology of whole plants also consistently reflects the results of long-term customisations in plant development. This is consistent with the poor correlation between photosynthesis and yields. The range of calculated $I_{0}$ values for the clones that were tested here oscillated between 21 and $33 \mu \mathrm{mol} \mathrm{m} \mathrm{m}^{-2} \mathrm{~s}^{-1}$ during the experimental period, demonstrating the efficiency of poplars under controlled low light intensities. However, this is not absolutely transferable to poplar plants under low light intensities when they are adapted to field conditions. Late summer and early autumn are often important for wood production (NELSON, 1984), as reflected in the results of net photosynthesis and $\mathrm{WUE}_{\text {intr }}$ for all clones in September. Strong seasonal variations in the measured physiological parameters were detected, varying from $50 \%$ to $20 \%$. This seasonality can be divided into 2 phases according to XU et al. (2003): 1) a spring maximum and 2) an early summer rapid decline. In this study, another phase was 
observed: a slight late summer increase close to senescence (IsEBRANDS et al., 1983). These variations can be primarily explained by the variations in temperature, phenology (LA) (ZHANG et al., 2006), radiation and the vapour pressure deficit in the greenhouse in which the plants were located for most of the experimental period, except when the measurements were collected. The seasonality of the photosynthetic parameters should be considered to maximise light use during the entire growing period and to obtain high biomass. The crown architecture, leaf area distribution and leaf orientation play important roles in plant productivity and its conversion into biomass (ZHANG et al., 2006; ISEBRANDS et al., 1988). Moreover, differences between sun and shade leaves are important in the overall photosynthetic performance of the tree (IsEBRANDS et al., 1983). The total leaf area is generally closely correlated with the accumulated biomass in poplar hybrids, and this correlation is thought to be genetically controlled. In this study, the two polyploid isogenic lines of the aspen hybrid Esch 5 confirmed this relationship with LA and SLA. The highest leaf mass occurred in L447, despite its low photosynthetic rates, which could be the reason for the higher wood production observed in this clone (LARSON et al., 1971). The results regarding biomass that are reported here showed an influence of ploidy level, but the effect of a different gene dosage remains unclear (HANSEN et al., 2007; RAMSEY, 2011). Leaf mass tended to be higher in all of the tetraploid lines, intermediate in the mixoploid lines and lower in the diploid lines. These results agree with the findings of SUN et al. (2011), QI et al. (2010), DHAWAN et al. (1996), WARNER et al. (1993), and Meng et al. (2014) in woody plants and with those of KAENSAKSIRI et al. (2011), Xu et al. (2014), Dehgan et al. (2012), and Caruso et al. (2011) in herbaceous species.

The ploidy level also influenced growth performance (WANG et al., 2014, PÄRNIK et al., 2014) with all of the mixoploid lines showing the highest growth rate within each clone at the end of the experimental period. The tetraploid growth rate was lower and differed significantly in all of the clones, demonstrating that polyploid plants do not always exhibit the best photosynthetic or biometric parameters. This conclusion was also verified by KAMINSKI et al. (1990), who revealed that $A_{\max }$ in polyploid wheat was highest in diploids, then decreased gradually at higher ploidy levels, while VAN LAERE et al. (2010) demonstrated that biomass production was lower in tetraploid individuals compared with their diploid progenitors in Spathiphyllum wallisii. Hull-SANDERS et al. (2009) found no evidence that polyploidy confers adaptive advantages in a particular environment. Furthermore, the results of VyAS et al. (2007) indicated that even when the photosynthetic rates of polyploid plants are higher than those of diploid plants, the ploidy level may not have been an immediate outcome of chromosome doubling. The adaptive significance of polyploidy remains untested because ecological studies cannot distinguish the effects of polyploidy per se from the genic evolution that occurs in all lineages, irrespective of ploidy. Consequently, studies on naturally occurring polyploids tend to overestimate the phenotypic and ecological consequences of genome duplication (RAMSEY, 2011; HANSEN et al., 2007). Keeping in mind that individual ecophysiological features do not appear to be the best indicators of field performance in all clones, a combination of several parameters may be used to predict field growth (CEulemans and IMPENS, 1980). In this study, photosynthetic and biometric processes that differed between clones and ploidy levels were analysed under controlled conditions in a greenhouse and climate chambers and were found to show considerable phenotypic plasticity; thus, it was very difficult to conclusively evaluate these traits. Nevertheless, results of PÄRNIK et al. (2014) showed that differences on A and growth became more pronounced with tree aging indicating that ontogeny plays an important role in expression of more productive genotypes.

The wood mass, volume and density also differed significantly with the ploidy level. The wood density and growth performance exhibited similar results: the mixoploid lines showed higher values for these parameters, close to those of the diploids, followed by the tetraploid clones. L447 outperformed the other two clones in these parameters. Density is one of the most important criteria for the categorisation of wood and fibre. A greater cell density generally leads to a higher wood density and is associated with the avoidance of wall collapse, enabling drought tolerance or resistance to cavitation (BRÉDA et al., 2006). Further research should test the vulnerability of mixoploid poplar clones to embolism because variants with a higher wood 
density should be more stable under water stress conditions. The availability of large numbers of poplar clone lines different in ploidy is still restricted. However, these results show that a continuation in this research testing poplar genotypes in the field would be interesting and justified. Therefore, a further detailed investigation of the performance is required to obtain a better understanding of their growth and productivity in terms of biomass production.

\section{Acknowledgements}

This project was funded and supported by the German Agency for Renewable Resources (FNR) under FKZ: 22012510. We would like to thank CHRISTINE EWALD for her valuable knowledge and help with the establishment of plant material, measurement protocols and technical analysis methods.

\section{References}

Bacon, M., M. Chaves, P. Gregory, L. Handley, H. Jones, B. Loveys, J. Osorio, J. Passioura, J. S. Pereira, J. Raven, M. Stoll, R. Tuberosa, S. Wilkinson, B. Wollenweber, J. YANG and J. ZHANG (2004): What is Water Use Efficiency? pp. 27-41. In: Water use efficiency in Plant Biology, edited by M. A. BACON, Wiley-Blackwell, Bodmin, Cornwall, United Kingdom.

BoARDMAN, N. K. (1977): Comparative photosynthesis of sun and shade plants. Annual Review Plant Physiology 28: 355-377.

Bréda, N., R. Huc, A. Granier and E. Dreyer (2006): Temperate forest trees and stands under severe drought: a review of ecophysiological responses, adaptation processes and long-term consequences. Annals Forest Science 63: 625-644.

Bunn, S. M., A. M. RAE, C. S. Herbert and G. TAYlor (2004): Leaf-level productivity traits in Populus grown in short rotation coppice for biomass energy. Forestry 27: 307-323.

Caemmerer, von S. and G. D. Farquhar (1981): Some relationships between the biochemistry of photosynthesis and the gas exchange of leaves. Planta 153: 376-387.

Carusoa, I., L. Lepore, N. De Tommasi, F. Dal Piaz, L. Frusciante, R. Aversano, R. Garramone and D. CARPuto (2011): Secondary Metabolite Profile in Induced Tetraploids of Wild Solanum commersonii Dun. Chemistry and Biodiversity 8: 2226-2237.

Ceulemans, R. (1990): Genetic variation in functional and structural productivity determinants in Poplar. Thesis Publishers, Amsterdam, 101 pp. ISBN 90-5170-044-X.
Ceulemans, R. and I. Impens (1980): Leaf gas exchange characteristics of seven poplar clones under laboratory conditions. Can J Forest Res 10: 429-435.

Ceulemans, R., I. Impens and R. Moermans (1980): The response of $\mathrm{CO}_{2}$ exchange rate to photosynthetic photon flux density for several Populus clones under laboratory conditions. Photosynthesis Research 1: 137-142.

Ceulemans, R., I. Impens and V. Steenackers (1987): Variations in photosynthetic, anatomical and enzymatic leaf traits and correlations with growth in recently selected Populus hybrids. Can J Forest Res 17: 273-283.

Ceulemans, R., R. F. Stettler, T. M. Hinckley, J. G. Isebrands and P. E. Heilman (1990): Crown architecture of poplar (Populus) clones as determined by branch orientation and branch characteristics. Tree Physiology 7: 157-167.

Dehghan, E., S. T. HäkKinen, K. OKsman-Caldentey and F. S. Ahmadi (2012): Production of tropane alkaloids in diploid and tetraploid plants and in vitro hairy root cultures of Egyptian henbane (Hyoscyamus muticus L.) Plant Cell Tiss Organ Cult 110: 35-44.

DhaWAN, O. P. and U. C. LAVANIA (1996): Enhancing productivity of secondary metabolites via induced polyploidy: a review. Euphytica 87: 81-89.

DiCKMANN, D. I., D. H. GJERSTAD and J. C GoRdon (1975): Developmental patterns of $\mathrm{CO}_{2}$ gas exchange, diffusion resistance and protein synthesis in leaves of Populus x euroamericana. Environmental and biological control of photosynthesis, pp. 171-181. In: Environmental and Biological Control of Photosynthesis, edited by R. MARCELle, Dr. W. Junk b.v., Publishers. The Hague, Netherlands.

Dickmann, D. I. and K. W. Stuart (1983): The culture of poplars in Eastern North America. MSU University publications, East Lansing, USA, 168 pp.

Ewald, D., K. Ulrich, G. NAujoks and M. B. SCHRÖDER (2009): Induction of tetraploid poplar and black locust plants using colchicine: chloroplast number as an early marker for selecting polyploids in vitro. Plant Cell Tiss Organ Cult 99: 353-357.

FARQUhAR, G. D., J. R. EHLERINGER and K. T. Hubick (1989): Carbon-isotope discrimination and photosynthesis. Annu Rev Plant Physiol Plant Mol Biol 40: $503-507$.

GonzÁlez CAstañón, M. L. and M. B. SchröDer (2002): Rapid determination of nuclear DNA amounts and ploidy levels in germplasms of Asparagus using flow cytometry. Acta Horticulturae 589: 193-199.

Gordon, J. C. and L. C. Promnitz (1976): Photosynthetic and enzymatic criteria for early selection of fast growing populus clones, pp. 79-97. In: Tree physiology and yield improvement - carbon fixation efficiency, edited by CANNELL, M. G. R and F. T. LAST, Academic press, London. 
Hansen, D. L., C. Lambertini, A. Jampeetong and H. BRIX (2007): Clone-specific differences in Phragmites australis: Effects of ploidy level and geographic origin. Aquatic Botany 86: 269-279.

Hull-Sanders, H. M., R. H. Johnson, H. A. Owen and G. A. MEYER (2009): Effects of polyploidy on secondary chemistry, physiology and performance of native and invasive genotypes of Solidago Gigantea (Asteraceae). American Journal of Botany 96: 762-770.

Isebrands, J. G., R. Ceulemans and B. M. Wiard (1988): Genetic variation in photosynthetic traits among Populus clones in relation to yield. Plant Physiology and Biochemistry 26: 427-437.

IsEBRANDS, J. G. and N. D. Nelson (1983): Distribution of ${ }^{14} \mathrm{C}$-labeled photosynthates within intensively cultured Populus clones during the stablishment year. Physiol Plant 59: 9-18.

Kaensaksiri, T., S. Puangpaka, N. SoOnthornchareONNON and S. PRATHANTURARUG (2011): In vitro induction of polyploidy in Centella asiatica (L.) Urban. Plant Cell Tiss Organ Cult 107: 187-194.

Kaminski, A., R. B. Austinf, M. A. Ford and C. L. Morgan (1990): Flag Leaf Anatomy of Triticum and Aegilops Species in Relation to Photosynthetic Rate. Ann Botany 66: 359-365.

KARAČIĆ, A. and M. WEIH (2006): Variation in growth and resource utilisation among eight poplar clones grown under different irrigation and fertilisation regimes in Sweden. Biomass and Bioenergy 30: $115-124$.

LARSON, P. R. and J. C. Gordon (1969): Photosynthesis and wood yield. Agricultural Science and Review 7: 7-14

LARSON, P. R. and J. G. IsEbrands (1971): The plastochron index as applied to developmental studies of cottonwood. Can J Forest Res 1: 1-11.

LAVANIA, U. C. (2005): Genomic and ploidy manipulation for enhanced production of phytopharmaceuticals. Plant Genetic Resource 3: 170-177.

LAWLOR, D. W. (1995): Photosynthesis, productivity and environment. J Exp Bot 46: 1449-1461.

Leal-Bertioli, S., D. J. Bertioli, P. M. Guimaraes, P. D. Pereira, I. Galhardo, J. P. Silva, A. C. M. Brasileiro, R. S. Oliveirs, P. I. Silva and V. VAdez (2012): The effect of tetraploidization of wild Arachis on Leaf morphology and other droughtrelated traits. Environ Exper Bot 84: 17-24.

Meng, F., M. Peng, H. PAng and F. Huang (2014): Comparison of photosynthesis and leaf structure on two black locust (Robinia pseudoacacia L.). Biochem Sys Ecol 55: 170-175.

Michael, D. A., D. I. Dickmann, J. G. Isebrands and N. D. NELSON (1990): Photosynthesis patterns during the establishment year within two Populus clones with contrasting morphology and phenology. Tree Physiology 6: 11-27.

Monclus, R., M. Villar, C. Barbaroux, C. Bastien, R. Fichot, E. Dreyer, F. M. Delmotte, D. Delay, J. Petit and C. Bre (2009): Productivity, water-use efficiency and tolerance to moderate water deficit correlate in 33 poplar genotypes from a Populus deltoides x Populus trichocarpa F1 progeny. Tree Physiology 29: 1329-1339.

Monclus, R., E. Dreyer, M. Villar, F. M. Delmotte, D. Delay, J. M. Petit, C. Barbaroux, D. Le Thiec, C. BRÈchet and F. BRIGNOlas (2006): Impact of drought on productivity and water-use efficiency in 29 genotypes of Populus deltoides x Populus nigra. New Phytol 169: 765-777.

MÜNTZING, A. (1936): The chromosomes of a giant Populus tremula. Hereditas 21: 383-393.

Nelson, N. D. (1984): Woody plants are not inherently low in photosynthetic capacity. Photosynthetica 18: $600-605$.

Nilsson-Ehle, H. (1936): Über eine in der Natur gefundene Gigasform von Populus tremula. Hereditas 21: 379-382.

PÄrniK, T., H. Ivanova, O. KeERBERG, R. VARDJA and U. NIINEMENTS (2014): Tree-age dependent changes in photosynthetic and respiratory $\mathrm{CO}_{2}$ exchange in leaves of micropropagated diploid, triploid and hybrid aspen. Tree Physiology 34: 585-594.

Poorter, H., Ü. Ninnemets, L. Poorter, I. J. Wright and R. VILlaR (2009): Causes and con-sequences of variation in leaf mass per area (LMA): a metaanalysis. New Phytol 182: 565-588.

QI, C., C. L. JIN, K. L. YIN, Z. X. YIN and H. ZHAO (2010): Comparison of Photosynthesis Characteristics between Different Ploidies of Populus ussuriensis Kom. Plant Physiology Journal 46: 917-922.

RAMSEY, J. (2011): Polyploidy and ecological adaptation in wild yarrow, pp. 7096-7101. In: Proceedings of the National Academy of Sciences Vol. 108, edited by D. FutuYMA, State University of NY, Stony Brook.

Stettler, R. F. and R. Ceulemans (1993): Clonal material as a focus for genetic and physiological research in forest trees, pp. 68-84. In: Clonal Forestry I: Genetics, Biotechnology, edited by M. R. AhuJA and W. J. LIBBY. Springer, Berlin, NY, USA.

SChulte, M., C. OfFER and U. HANsen (2003): Induction of $\mathrm{CO}_{2}$ gas exchange and electron transport: comparison of dynamic and steady-state responses in Fagus sylvatica leaves. Trees 17: 153-163.

Sun, Q., H. Sun, R. L. BELL, H. LI and L. XIN (2011): Variation of phenotype, ploidy level, and organogenic potential of in-vitro regenerated polyploids of Pyrus communis. Plant Cell Tiss Organ Cult 107: 131-140.

TAMBUssi, E., J. BorT and J. ARAUs (2007): Water use efficiency in C3 cereals under Mediterranean conditions: a review of physiological aspects. Ann Appl Biol 150: 307-321.

UlRICH, K., A. UlRICH and D. EwALD (2008): Diversity of endophytic bacterial communities in poplar grown under field conditions. FEMS microbiology ecology 63: 169-180.

VÄINÖLÄ, A. (2000): Polyploidization and early screening of Rhododendron hybrids. Euphytica 112: 239-244. 
Van Laere, K., S. C. Franç, H. Vansteenkiste, J. Van Huylenbroeck, K. Steppe and M. C. Van LABEKE (2011): Influence of ploidy level on morphology, growth and drought susceptibility in Spathiphyllum wallisii. Acta Physiologiae Plantarum 33: 1149-1156.

Vyas, P. M., S. Bisht, S. I. Miyazawa, S. Yano, K. Noguchi, I. Terashima and S. FunayamaNoGUCHI (2007): Effects of polyploidy on photosynthetic properties and anatomy in leaves of Phlox drummondii. Funct Plant Biol 34: 673-682.

WANG, L., F. GAO, K. XU and X. Li (2014): Natural occurrence of mixoploid ginger (Zingiber officinale Rosc.) in China and its morphological variations. Sciencia Horticulturae 172: 54-60.

WARNER, D. A. and G. E. EDWARDS (1993): Effects of Polyploidy on Photosynthesis. Photosynthesis Research 35: 135-147.

Webb, W. L., M. Newton and D. Starr (1974): Carbon dioxide exchange of Alnus rubra - a mathematical model. Oecologia 17: 281-291.

XU, L. and D. BALDOCCHI (2003): Seasonal trends in photosynthetic parameters and stomatal conduc- tance of blue oak (Quercus douglasii) under prolonged summer drought and high temperature. Tree Physiology 23: 865-877.

Xu, C., T. Tang, R. Chen, C. Liang, X. LiU, C. WU, Y. YANG, D. YANG and H. WU (2014): A comparative study of bioactive metabolite production in diploid and tetraploid Echinea purpurea (L.) Moench. Plant Cell Tiss Organ Cult 116: 323-332.

Zhang, L. M., G. Yu, X. Sun, X. Wen, C. Ren, Y. Fu, Q. LI, Z. LI, Y. LIU, D. GUAN and J. YAN (2006): Seasonal variations of ecosystem apparent quantum yield $(\alpha)$ and maximum photosynthesis rate $\left(\mathrm{P}_{\max }\right)$ of different forest ecosystems in China. Agric For Meteorol 137: 176-187.

Zsuffa, L., E. Giondano, L. D. Pryor and R. F. STETTLER (1996): Trends in poplar culture: some global and regional perspectives, pp. 515-539. In: Biology of Populus and its Implications for Management and Conservation, Part II, edited by R. F. Stettler, H. D. Bradshaw JR., P. E. Heilman and T. M. Hinckley. NRC Research Press, National Research Council of Canada, Ottawa.

\title{
Estimation of genetic parameters for height using spatial analysis in Tsuga heterophylla full-sibling family trials in British Columbia
}

\author{
By E. P. CAPPA ${ }^{1,2), 3), *)}$, A. D. YANCHUK ${ }^{2)}$ and C. V. CARTwRIGHT ${ }^{2)}$
}

(Received 15 ${ }^{\text {th }}$ August 2014)

\begin{abstract}
Non-spatial and spatial analyses were carried out to study the effects on genetic parameters in ten-year height growth data across two series of 10 large second-generation full-sib progeny tri-

\footnotetext{
1) Department of Forest Sciences, 2424 Main Mall, University of British Columbia, Vancouver, British Columbia, V6T 1Z4, Canada.

2) British Columbia Ministry of Forests and Range, Research Branch, PO Box 9519 Stn Prov Govt, Victoria, British Columbia, V8W 9C2 Canada.

$\left.{ }^{3}\right)$ Permanent address: Instituto Nacional de Tecnología Agropecuaria (INTA), Instituto de Recursos Biológicos, De Los Reseros y Dr. Nicolás Repetto s/n, 1686, Hurlingham, Buenos Aires, Argentina - Consejo Nacional de Investigaciones Científicas y Técnicas (CONICET), Argentina.
}

als of western hemlock [Tsuga heterophylla (Raf.) Sarg.] in British Columbia. To account for different and complex patterns of environmental heterogeneity, spatial single trial analyses were conducted using an individual-tree mixed model with a two-dimensional smoothing surface with tensor product of B-spline bases. The spatial single trial analysis, in all cases, showed sizeable lower Deviance Information Criterion values relative to the non-spatial analysis. Also,

\footnotetext{
*) Corresponding author: EdUardo Pablo CAPPA. Bosques Cultivados, Instituto de Recursos Biológicos, Centro de Investigación en Recursos Naturales, Instituto Nacional de Tecnología Agropecuaria, De Los Reseros y Dr. Nicolás Repetto s/n, 1686 Hurlingham, Buenos Aires, Argentina. Phone/Fax: +54 1146210433. E-Mail: cappa.eduardo@inta.gob.ar
} 